\title{
E-Government Effectiveness and Efficiency in EU-28 and COVID-19
}

\author{
Sabina Hodžić \\ University of Rijeka, Faculty of Tourism and Hospitality Management, Croatia \\ sabinah@fthm.hr \\ http://orcid.org/0000-0002-4202-3548 \\ Dejan Ravšelj \\ University of Ljubljana, Faculty of Public Administration, Slovenia \\ dejan.ravselj@fu.uni-lj.si \\ https://orcid.org/0000-0003-0426-820X \\ Dubravka Jurlina Alibegović \\ The Institute of Economics Zagreb, Croatia \\ djurlina@eizg.hr \\ http://orcid.org/0000-0002-0424-7583
}

Received: 24. 2. 2021

Accepted: 10. 5. 2021

\section{ABSTRACT}

The task of every government, especially during the Covid-19 pandemic, is to provide services and goods for citizens and to maintain economic order. Therefore, the combination of legislation, the judiciary and administration is inevitable. Moreover, public administrations must transform the way they function by using more information and communication technology in order to remain responsive and efficient. This challenge was further revealed during lockdowns in individual countries, which affected their social and economic development. The solution to that challenge is the implementation of e-government in the public sector. It also increases innovation in governance processes as well as efficiency and effectiveness by offering more participative opportunities to citizens. Hence, a mature level of e-government development also arises. Nevertheless, there are significant differences among the levels of e-government development in the EU-28. The aim of this article is to assess the influence of e-government maturity on government effectiveness and efficiency in the EU-28. In order to obtain empirical results, a two-stage least square regression (2SLS) was applied. The empirical results show that e-government maturity positively and significantly contributes to enhancing government effectiveness and efficiency in the EU-28. In addition, the rule of law plays an important role in each stage regression model. Based on the empirical results, we can conclude that e-government is 
inevitable and should ensure the proper functioning of public administration during the Covid-19 pandemic.

Keywords: e-government, Covid-19 measures, government efficiency, government effectiveness, two-stage least squares regression analysis

JEL: H11, H7O, H8

\section{Introduction}

The COVID-19 pandemic has affected every aspect of human lives, social and economic development, as well as the proper functioning of public administration. The only way to stop spreading the COVID virus has been social distance and self-isolation. Therefore, the quality of e-government must be improved and made publicly available to everyone. This practice requires the combination of e-governance with the innovative use of existing and advanced technologies (Shaw et al., 2020). Hence, in the light of the rapid use of information and communication technology (ICT), the public sector and administration have been faced with dynamic challenges. One of these challenges is to implement e-government that will support digitalization of the public sector by enabling its openness, transparency and effectiveness. By doing so, the public sector and administration will be fundamentally transformed. E-government can be described as an electronic exchange of information and services with citizens, businesses and other sections of government, and includes open government data and the use of information and communication technologies to allow innovation in governance (United Nations, 2020). The goal of e-government is the use of technological communications devices (computers, cell phones, tablets and the Internet) and different digital methods in government activities to achieve efficiency and effectiveness in providing public services to all users. As such, it provides conditions to citizens and entrepreneurs for direct and appropriate access to the government as well as for the proper delivery of services. This is possible through an effective e-governance institutional framework that provides conditions for the provision of quality public services which meet the requirements of citizens for transparency, accountability and inclusivity, which contributes to increasing the trust of citizens in their governments. In addition, the United Nations (2020) distinguish several types of digital interactions - digital relations between a citizen and their government (C2G), between governments and other government organizations (G2G), between government and citizens (G2C), between government and employees (G2E) and between government and businesses (G2B). To monitor the results and impacts of these digital interactions, the United Nations implemented the United Nations E-Government Survey. The E-Government Survey presents a systematic assessment of the use and possible usage of modern technologies to change the public sector by improving efficiency, effectiveness, transparency, accountability, access to public services and citizen participation in all member states (193) of the United Nations. 
Decades ago, developed countries began to take advantage of advanced technology by providing online public services. Today, almost all the EU countries have a range of public services provided as e-services. Estonia is the leading European country recognized as "the most advanced digital society in the world". Estonia has created an efficient, secure and transparent system where 99 percent of governmental services are online. Numerous solutions have been developed, such as e-Governance containing four sections - Government Cloud, Data Embassy, i-Voting and e-Cabinet. Other European countries are intensively researching and working to improve e-government solutions. The European Union supports this objective because one of the strategic priorities for the period 2019-2024 refers to "Europe fit for the digital age - Empowering people with a new generation of technologies". The EU's digital strategy "Shaping Europe's digital future" aims to bring about the transformation of work for people and businesses. It consists of three main pillars to ensure that Europe gives its citizens, businesses and governments control over the digital transformation. In implementing the digital strategy, the EU has developed an e-Government Action Plan, which provides sources of information and guides to support local and regional administrations. This is especially important during the COVID-19 pandemic, since most of the government services needed to be made available online due to the lockdown. The COVID-19 pandemic has made it crystal clear that without efficient and effective online government services, most of the public function will not be achieved or be sustainable. In addition, Ullah et al. (2021) found that internet technology and e-governance enhancement during the COVID-19 pandemic have helped to combat COVID-19-related impacts. Moreover, researchers have also explored expectations created by public managers, policymakers and stakeholders concerning the implementation of e-government policies and applications. They have tried to verify whether e-government applications have been introduced according to the real demands from citizens and to evaluate whether e-government solutions have been effective (Rodríguez Bolívar, 2014). Based on all of the aforementioned, our hypothesis is that e-government maturity is positively and significantly associated with government effectiveness and efficiency.

As not much is known about the effectiveness and efficiency of e-government in the EU-28, the main aim of the paper is to assess the influence of e-government maturity on government effectiveness and efficiency in the EU-28 as a solution to improve public functioning during the COVID-19 pandemic. Accordingly, the paper contributes to existing literature in the following way. Firstly, it provides a detailed literature overview of the research in the field of government effectiveness and efficiency and COVID-19 measures in the EU. Secondly, it investigates the relationship between e-government maturity and government effectiveness and efficiency in the EU-28. The remainder of the рарег is structured as follows. After the introduction, a brief literature review and theoretical framework are presented. The following section describes the data and research methods. In Section Four, the empirical results are presented. The paper ends with conclusion remarks and recommendations for further research. 


\section{Literature review and theoretical framework}

In the existing literature there are not many papers that examine both government efficiency and effectiveness with regard to promoting e-government development activity in the EU member countries.

Efficiency and effectiveness are two measures that are related to the results and outcomes of the functioning of each government. Efficiency determines how much each unit of output (e.g., public services provided) costs, and effectiveness measures the quality of that output or outcomes in providing public services. In the other words, public sector efficiency can be defined as the output relative to the resources employed, and public sector effectiveness (performance) can be defined as the outcome of public sector activities. Effectiveness is explicitly mentioned as one of the five political principles in the White Paper on European Governance. Based on the researched literature, it can be determined that for certain groups of countries, especially those that are underdeveloped, there is a lack of research that measures the efficiency and effectiveness of the public sector with a special emphasis on e-government. However, these measurements for different countries are inadequate.

The conducted research indicates that the efficiency of governments is most often monitored through the achieved results of their budget policies, i.e., the efficiency or inefficiency of public expenditures. Research has shown that there are significant differences in the efficiency of public spending between countries. In developing countries, the efficiency of government spending is primarily determined by a country's structural variables and governance indicators (Rayp and Van De Sijpe, 2007; Gupta and Verhoeven, 2001). In addition to fiscal indicators, for instance the share of tax revenues and public expenditures in the gross domestic product, the efficiency of the government's role in the economy can be monitored by the results of non-fiscal instruments, such as regulations, direct budget subsidies, subsidized loans etc. Non-fiscal instruments are more widely used in transition and less developed countries and are intended to achieve the same goals that should be achieved by the fiscal instruments (Tanzi, 1995, 1998).

Afonso et al. (2003) examined public sector efficiency and effectiveness (performance) using performance indicators for 23 industrialized countries. They examined the efficiency of public sectors using total public spending and several spending categories as substitutes for used funds. They analyzed them in relation to performance indicators as the opportunity costs of public sector activities. Efficiency for each country is presented by a ratio of performance indicators and public spending indicators. The effectiveness of the public sector is calculated by input and output efficiency, ranking countries in terms of public spending efficiency. The results of the research showed that there are no significant differences in effectiveness among the analyzed countries. Countries with a relatively small public sector have a higher level of efficiency as opposed to those with a large public sector. Tanzi et al. (2007) conducted additional research the results of which changed somewhat. They found that countries with smaller public sectors had higher performance levels, as measured by 
their performance index, than countries with a larger public sector. Additionally, countries with a smaller public sector were more efficient in achieving their public sector performance levels than countries with a larger public sector. Research conducted by Hauner and Kyobe (2010) resulted in similar conclusions. Their research on public sector performance and efficiency based on data for 114 countries revealed a lower level of efficiency in the case of higher government expenditure in relation to gross domestic product. In addition, they concluded their research with analytical evidence that richer countries are characterized by better public sector performance and efficiency.

Government effectiveness is presented as part of the World Governance Indicators prepared by the World Bank. Kaufmann et al. (2010) presented the methodology of the Worldwide Governance Indicators, which consists of six dimensions of governance, namely voice and accountability, political stability and absence of violence, government effectiveness, regulatory quality, rule of law and control of corruption. One of the six governance dimensions defines government effectiveness as perceptions of the quality of public services, the quality of the civil service and the degree of its independence from political pressures, the quality of policy formulation and implementation as well as the credibility of the government's commitment to such policies. For example, developed countries like Denmark and Switzerland show a high level of government effectiveness (percentile rank is about 100), unlike Croatia, where government effectiveness is not high, and the rank has decreased from 73 (2014) to 67 (2019). In terms of the degree of democracy, research has shown interesting results. In countries with a high degree of democracy, it does not mean that it will automatically contribute to the efficient and economical delivery of public services. An example of this is Belgium, as a country with a high degree of democracy, where the level of efficiency has decreased, and the rank has changed from 88 (2014) to 80 (2019) and Ireland with a decreased rank from 91 (2014) to 86 (2019).

In the conducted research, Mandl et al. (2008) presented the conceptual framework for the efficiency and effectiveness of government spending as a link between inputs of resources, outputs of goods and services and outcomes in terms of accomplishment of goals. Their conclusion is that "the greater the output for a given input or the lower the input for a given output, the more efficient the activity is" (Mandl et al., 2008, p. 3). The level of government efficiency and effectiveness differs throughout the European Union. Mandl et al. (2008) presented an analytical framework for examining the effectiveness and efficiency of public spending in the EU. Their research was focused on innovation and expenses for research and development. Their findings show a positive relationship between an innovation index and spending on research and development, but they considered that this result does not mean that a high level of spending will automatically increase the innovation level. It is related to other institutional factors. Research has shown that efficiency and effectiveness vary between countries for several reasons, which can be grouped into the following: data coverage and collection are different across countries, the composition of government spending and its effects on the 
efficiency of public services varied, government interventions on the economy includes not only taxing and spending, but borrowing and regulation (Di Matteo, 2013). Few surveys on government efficiency and effectiveness have been conducted in the new EU member states. Using various performance indicators, Slijepčević (2010) measured the efficiency and effectiveness of public administration in Croatia, comparing it with that of EU member states to determine whether and to what extent Croatia should implement reforms to increase the efficiency and effectiveness of its public administration. The Zugravu and Sava (2012) study presents the impact of restrictive fiscal and budgetary policies on the efficiency and performance of Romania's public sector between 2008 and 2011.

Government effectiveness and efficiency in providing public services can be measured by different indicators. Theoretical literature indicates that the type and number of indicators used depends on political, economic and cultural inequalities across countries. These inequalities influence the difference in the effect of e-government solutions on government effectiveness and efficiency. Based on the conducted scientific research, the literature presents numerous limitations of countries in the greater application of e-government solutions. Many countries face insufficient capacities for digital transformation to provide quality, accessible, reliable, fast, personalized, secure and inclusive public services at appropriate prices and to make them available according to the needs of the residents and entrepreneurs using open and participatory mechanisms. The key conclusions are contained in the United Nations E-Government Survey (United Nations, 2020). The latest survey, which was conducted in 2020, suggests that the countries at the most advanced levels of the e-government development index have allocated priority to developing capacities for digital government transformation. Countries with a high or very high e-government development index use information and communications technology to improve operational linkages between policymaking and service delivery. Countries that are at the bottom of the e-government development index ranking face the problem of underdeveloped institutions with regard to promoting the integration of processes and data among agencies and levels of government regarding public services delivery. Nam (2019) conducted research regarding the influence of e-government maturity on government effectiveness and efficiency as a cross-country review. The analysis based on various global indicators revealed that e-government significantly contributes to increasing government effectiveness, but did not contribute to improving government efficiency. There are many reasons for these results. For example, the political, economic and cultural differences across countries affect various impacts of e-government maturity on government effectiveness and efficiency.

Numerous other studies have been conducted on the impact of e-government in several key areas, for instance on public sector modernization and efficiency (OECD, 2010), effectiveness and efficiency (Eyob, 2004; Hackney et al. 2007), transparency (Bertot et al., 2012; Ciborra, 2005; Relly and Sabharwal, 2009), trust in government (Grimmelikhuijsen et al., 2013), anti-corruption (Andersen, 2009), public service quality (Reddick, 2006, 2009; Welch et 
al., 2005; West, 2004; Lindgren and Jansson, 2013), accountability (Justice et al., 2006; Pina et al., 2007), and approaches/measures against COVID-19 (Open Government Partnership, 2020, Council of Europe, 2020). On a panel data set for the period 2002-2008, Das et al. (2017) found that e-government matured faster with rising affluence of gross domestic product per capita and improvements in information and communication technology infrastructure. Hence, all research shows that digital government will improve public service delivery, increase citizens' trust and increase transparency, accountability and inclusion, which will make life better for all the constituents of the country.

\subsection{COVID-19 government measures in the EU-28}

Today, at the time of the COVID-19 pandemic, the role of digital government is crucial in promoting the health and safety of citizens and ensuring the conditions for the smooth functioning of public services. Digital technologies enable the connection of governments and people and facilitate governments' attempts to prepare and implement policy decisions based on up-to-date data and information, which is a condition for efficient management of public funds for the provision of public services to all users. During the COVID-19 pandemic, governments are sharing their information through national portals, mobile applications and social media platforms. In addition, many governments have been active in promoting open government data, both in terms of releasing data and re-using them to build different types of data products (OECD, 2021). The United Nations E-Government Survey for 2020 (United Nations, 2020) shows that the majority of governments have high levels of transparency in reporting and sharing crisis-related information. In the minority are governments that must develop systems of online services to participate in the fight against COVID-19. The survey reported that during year 2020, governments used more social media channels to report on COVID-19 statistics (e.g., total number of cases in a country, total fatalities as well as reporting cases by jurisdictions). By observing only, the EU-28, the eGovernment Benchmark study provides interesting results about the efficiency of digital public services. As such, it evaluates the performance of online public services that accelerate the digital transformation of e-government in the fields of modernizing public administration, improving cross-border mobility and designing and delivering new digital services to improve digital interaction. Based on the results (European Commission, 2020, p. 7), the European frontrunners in e-government are Malta (overall score of 97\%), Estonia (92\%), Austria (87\%) and Latvia (87\%). This is the evidence that despite the COVID-19 pandemic, countries have recognized the importance of digital government and they are now improving their development. Hence, the COVID-19 crisis has encouraged new initiatives for regional digital cooperation in the fields of digital connectivity, data governance, e-learning, technological resilience and digitalization of public services delivery. In addition, cities are also playing a major role in the pandemic. City portals have offered information to guide people to COVID-19-related services offered by central governments. Sharing the public COVID-19 data was a key component of the urban emergency 
response. With cities in lockdown, new e-services have been developed. For example, Estonia has developed a community engagement application that lets local governments distribute information and guidelines to prevent the spread of the coronavirus. In Sofia, Bulgaria, the city administration initiated an application through which citizens can report on the COVID-19 social distancing orders to support the work of police officers. In Barcelona, Spain, a new economic recovery project called "Barcelona Never Stops" has been established. The aim was to implement a series of measures aimed at the regeneration of the economic and social network, as well as at the economic stimulation of the city. In Paris, France, a plan to support businesses, cultural actors and associations has been developed. Their measures include the following engagements for the next five years: 9 out of 10 service providers of the city will be SMEs, 6 million EUR will be invested in businesses, artisans, cultural enterprises and young innovative firms, 5 million EUR will support the tourism sector and 4 million EUR will support actors of the social and solidarity-based economy (OECD, 2020, p. 72). Additionally, governments in many countries have also studied new ways of using technology to communicate with older persons to help prevent their social isolation. Also, more governments have started integrating new technologies, such as artificial intelligence and block chain technology in digital government strategies.

During the COVID-19 lockdown and other restrictions, online services are being encouraged in countries that agree to use more e-government solutions to promote quality and availability. A precondition for the development of an online service is an investment in strengthening digital skills, because they can support social inclusion and help to react to an emergency (Ullah et al., 2020). In practice, other EU countries have developed various online solutions. These solutions can be grouped into several categories. Online payment systems аге more efficient, faster, more convenient and economical than a traditional payment system and are strongly supported in many countries. During the COVID-19 pandemic, the implementation of digital health is desirable because of its direct effect on the reduction of health risks. Alwashmi (2020) expressed that, for COVID-19, a free triage tele-health assessment is an appropriate way to provide health services to citizens and has been proposed by the health institutions of many countries. Therefore, to combat COVID-19, many governments are taking appropriate measures where the publicly available data are created by ACAPS (2020) on their website. The COVID-19 government measures dataset contains a list of all measures implemented by governments worldwide in response to the coronavirus pandemic. The data collection includes a secondary data review in five categories: social distancing, movement restrictions, public health measures, social and economic measures and lockdowns. Moreover, governments have undertaken several stimulus packages, including fiscal and monetary measures to support households, health care, manufacturing, liquidity, public administration and others (Bayer et al., 2020; Cheng et al., 2020; Gourinchas et al., 2020; Siddik, 2020; Narayanan et al., 2021). 


\section{Data and research methods}

Nowadays, the term "e-government" has being considered as key instrument of modernizing government. Therefore, the theoretical literature was primarily focused on the evaluation of the impact of new technologies and e-government applications. In his study, Heeks (1999) found the benefits gained by e-government, such as increased efficiency, decentralization, increased accountability, improved resource management and marketization. Following the guidelines for the economic policies of the EU member states, i.e. Digital Agenda, e-government is one of the key areas where further progress is necessary. The impact of effective e-government implementation offers benefits, such as the improvement in information quality and information supply, reduction of process time, reduction of administrative burdens, impact of service quality and user satisfaction, cost reduction, and impact of e-government on economic growth and social development. Based on all of the aforementioned, the improvement in the relationship between citizens and public entities for high-quality public services increases the effectiveness and efficiency of public administration. Similar research was done by Nam (2019), where he examined the influence of e-government maturity on government effectiveness and efficiency as a cross-country review in the world. Therefore, our paper is focused on the assessment of the influence of e-government maturity on government effectiveness and efficiency in the EU-28. The paper utilizes a dataset which has been compiled from different data sources for each EU-28member country, similar as in a research project by Nam (2019). In Table 1 a summary of variables considered in the empirical analysis is presented. 


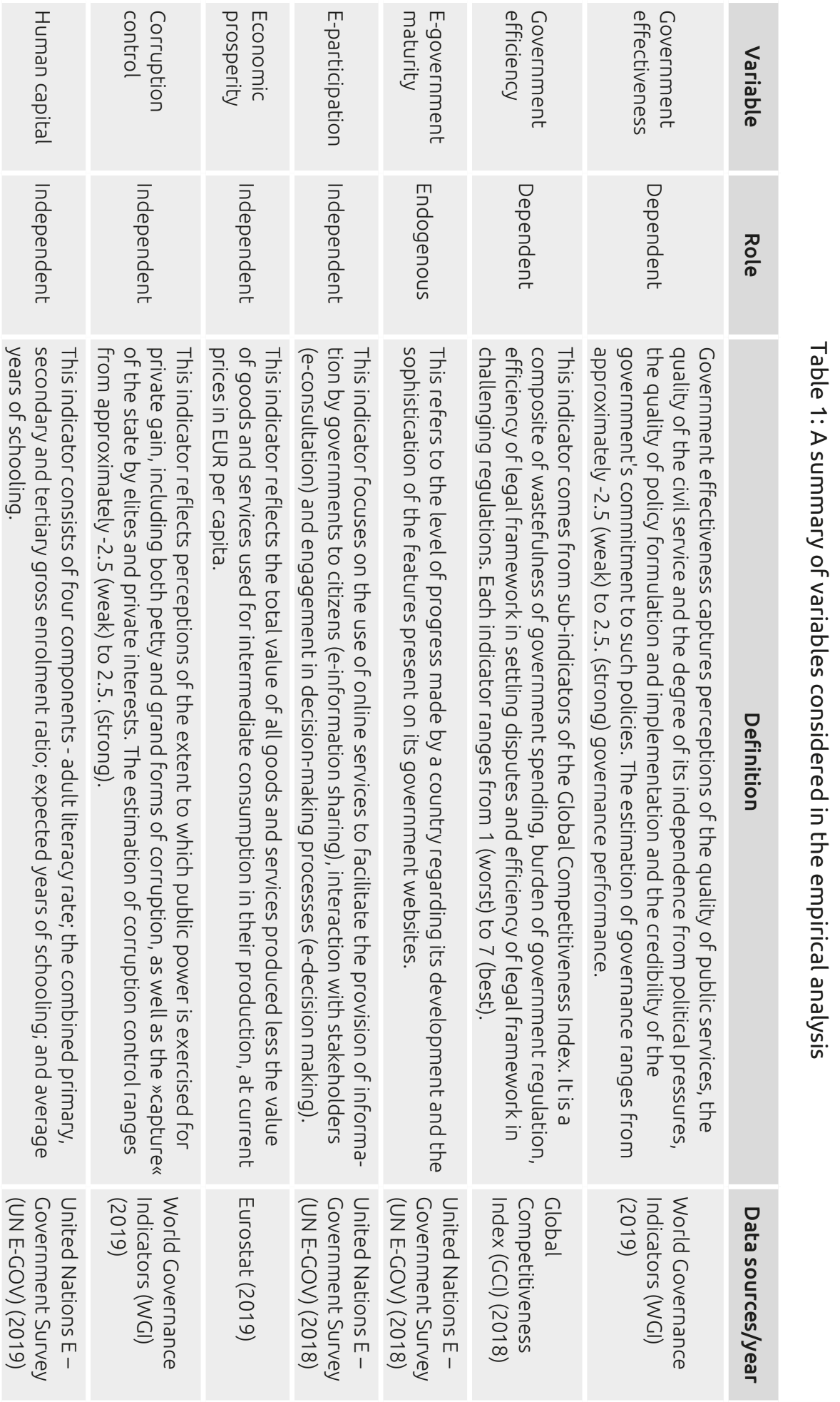







The assessment of the influence of e-government maturity on government effectiveness and efficiency in the EU-28 is estimated on the basis on a national cross-sectional dataset for each EU-28 member state for 2019, except for the variables government efficiency (2018), e-government maturity (2018) and e-participation index (2018), due to the lack of the latest data. Due to the endogenous nature of e-government maturity and under the assumption that political and economic determinants influence its level, a two-stage ordinary least squares (2SLS) regression analysis is employed. This methodological approach is commonly accepted in econometrics to estimate parameters in systems of linear simultaneous equations and to solve problems of omitted-variables bias in single-equation estimation (Angrist and Imbens, 1995), Accordingly, this type of regression emphasizes the model with endogenous explanatory variables in a linear regression framework. It consists of four types of variables - dependent, exogenous, endogenous and instrument variables. Table 2 presents the descriptive statistics, namely the mean, standard deviation, minimum and maximum values for the variables considered in the empirical analysis.

Table 2: Descriptive statistics

\begin{tabular}{|l|c|c|c|c|c|}
\hline Variables & Obs & Mean & Std. Dev. & Min & Max \\
\hline effectiveness & 28 & 1.065 & 0.550 & -0.280 & 1.938 \\
\hline efficiency & 28 & 3.675 & 0.964 & 2.3 & 5.4 \\
\hline egovmat & 28 & 0.802 & 0.070 & 0.667 & 0.915 \\
\hline epart & 28 & 0.865 & 0.105 & 0.618 & 1 \\
\hline democracy & 28 & 7.913 & 0.868 & 6.49 & 9.39 \\
\hline polstab & 28 & 0.729 & 0.279 & 0.29 & 1.36 \\
\hline ecoproln & 28 & 10.198 & 0.585 & 9.080 & 11.535 \\
\hline ecofre & 28 & 69.814 & 5.985 & 57.7 & 80.5 \\
\hline corrcon & 28 & 0.978 & 0.788 & -0.16 & 2.15 \\
\hline rulelaw & 28 & 1.101 & 0.592 & 0.04 & 2.02 \\
\hline humcap & 28 & 0.863 & 0.057 & 0.78 & 0.97 \\
\hline powdis & 28 & 52.107 & 20.737 & 11 & 100 \\
\hline indiv & 28 & 57.964 & 17.856 & 27 & 89 \\
\hline masc & 28 & 45.786 & 24.142 & 5 & 100 \\
\hline uncavo & 28 & 70.750 & 21.592 & 23 & 100 \\
\hline empratio & 28 & 13.635 & 20.693 & 0.460 & 113.682 \\
\hline
\end{tabular}

Source: Authors' calculation. 
The empirical strategy of our analysis consists of several stages. The first stage regresses e-government maturity on e-participation, economic prosperity, corruption control and human capital. In this regression we added an additional variable, i.e., e-participation, which does not exist in the analysis of Nam (2019). The second stage regresses government effectiveness and efficiency on traditional and specific determinants. The traditional determinants are democracy, political stability, economic freedom, rule of law and Hofstede's $(1980,1983)$ four cultural dimensions (power distance, individualism, masculinity and uncertainty avoidance). Specific determinants are e-participation, economic prosperity, corruption control, human capital and public employee ratio. In particular, the broadness of the government effectiveness and efficiency concepts requires a comprehensive consideration, including the political administrative system, economic development, and institutional and cultural contexts, as discussed in the mainstream literature on government effectiveness and efficiency (Schuppan, 2009). Moreover, as the e-government model has led to reducing public sector employees, we analyzed a 2SLS regression with and without the public employee ratio for each dependent variable.

\section{Empirical results}

In order to support the research hypothesis stated in introduction and before describing the 2SLS analysis, we checked Pairwise correlation coefficients. The Pairwise correlation coefficients between variables considered in the empirical analysis are presented in Table 3.

Based on the results from Table 3, we can conclude that there is a high correlation between bivariate relationships. E-government maturity is highly correlated with government effectiveness $(r=0.803)$ and government efficiency $(r=0.765)$. Besides this variable, variables like democracy $(r=0.900 ; r=0.839)$, economic prosperity $(r=0.811 ; r=0.778)$, corruption control $(r=0.927 ; r=$ $0.889)$ and rule of law $(r=0.946 ; r=0.852)$ are also in high correlation with both dependent variables. Cultural dimension variables such as power distance, masculinity and uncertainty avoidance are not significantly or highly correlated with both dependent variables. The results of the empirical analysis for the assessment of the influence of e-government maturity on government effectiveness and efficiency in the EU-28 are presented in Table 4. 


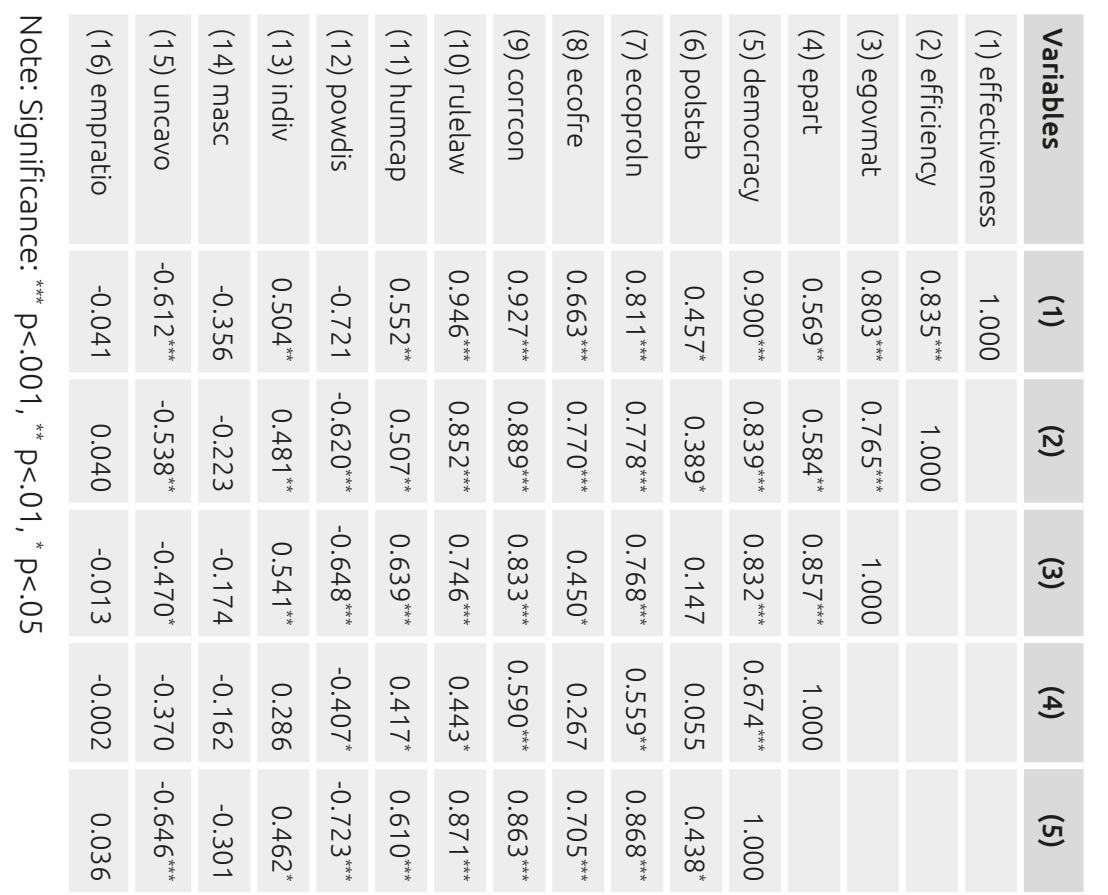

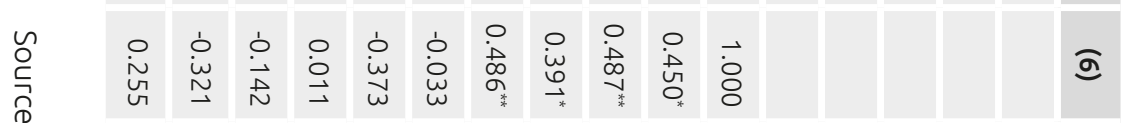

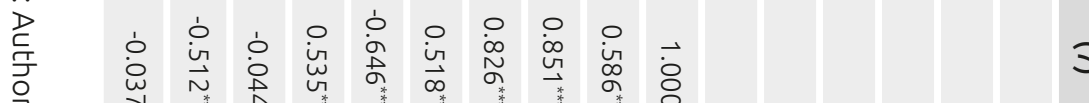

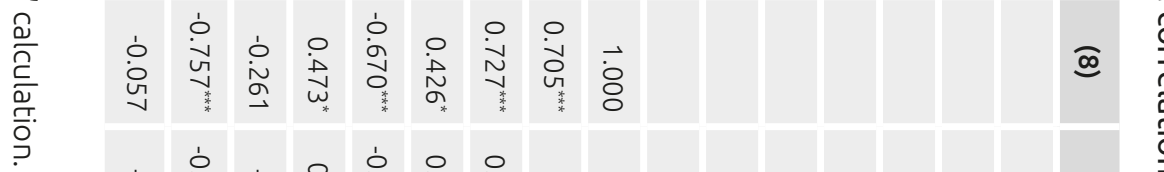



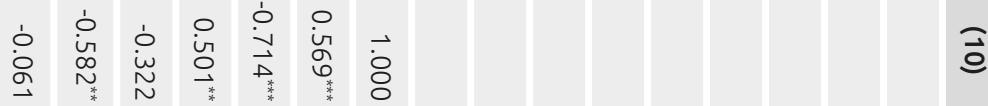

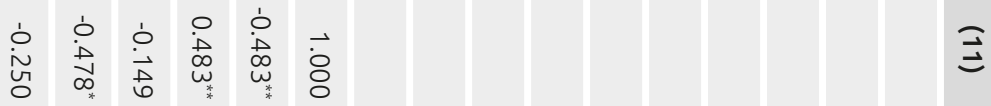

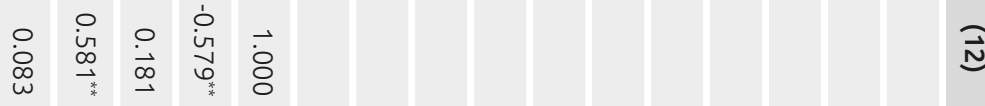

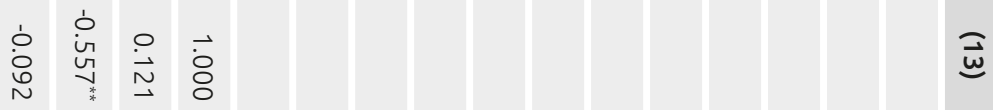

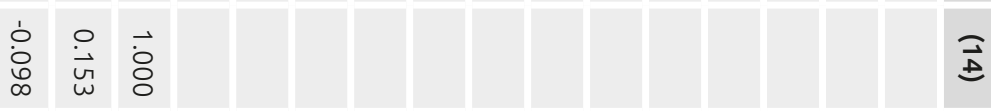

\begin{tabular}{|l|l|l|l|l|l|l|}
$\stackrel{\circ}{\vec{v}}$ & $\overrightarrow{\dot{8}}$ & $\overrightarrow{\vec{v}}$ \\
\hline
\end{tabular}

$\overrightarrow{8}$ 
Table 4: Regression results of government effectiveness and efficiency

\begin{tabular}{|c|c|c|c|c|c|}
\hline & $\begin{array}{c}\text { First stage } \\
\text { predicting } \\
\text { e-government } \\
\text { maturity }\end{array}$ & $\begin{array}{l}\text { Second stage } \\
\text { predicting } \\
\text { government } \\
\text { effectiveness }\end{array}$ & $\begin{array}{l}\text { Second stage } \\
\text { predicting } \\
\text { government } \\
\text { effectiveness }\end{array}$ & $\begin{array}{l}\text { Second } \\
\text { stage } \\
\text { predicting } \\
\text { government } \\
\text { efficiency }\end{array}$ & $\begin{array}{l}\text { Second } \\
\text { stage } \\
\text { predicting } \\
\text { government } \\
\text { efficiency }\end{array}$ \\
\hline $\begin{array}{l}\text { E-government } \\
\text { maturity }\end{array}$ & & $\begin{array}{l}1.899^{*} \\
(0.914)\end{array}$ & $\begin{array}{l}1.897^{*} \\
(0.879)\end{array}$ & $\begin{array}{l}5.942^{* *} \\
(2.09)\end{array}$ & $\begin{array}{l}6.691^{* * *} \\
(1.979)\end{array}$ \\
\hline E-participation & $\begin{array}{l}0.363^{* * *} \\
(0.051)\end{array}$ & & & & \\
\hline $\begin{array}{l}\text { Democracy } \\
\text { squared }\end{array}$ & & $\begin{array}{l}-0.081^{*} \\
(0.037)\end{array}$ & $\begin{array}{l}-0.094^{*} \\
(0.038)\end{array}$ & $\begin{array}{l}0.225^{\text {** }} \\
(0.085)\end{array}$ & $\begin{array}{l}0.265^{* *} \\
(0.086)\end{array}$ \\
\hline Democracy & & $\begin{array}{c}1.317^{*} \\
(0.583)\end{array}$ & $\begin{array}{l}1.557^{*} \\
(0.608)\end{array}$ & $\begin{array}{l}-3.37^{\star} \\
(1.333)\end{array}$ & $\begin{array}{l}-4.137^{\star *} \\
(1.368)\end{array}$ \\
\hline $\begin{array}{l}\text { Political } \\
\text { stability }\end{array}$ & & $\begin{array}{c}0.24 \\
(0.127)\end{array}$ & $\begin{array}{l}0.312^{*} \\
(0.141)\end{array}$ & $\begin{array}{l}-0.194 \\
(0.289)\end{array}$ & $\begin{array}{l}-0.379 \\
(0.318)\end{array}$ \\
\hline $\begin{array}{l}\text { Economic } \\
\text { prosperity }\end{array}$ & $\begin{array}{c}0.015 \\
(0.014)\end{array}$ & & & & \\
\hline $\begin{array}{l}\text { Economic } \\
\text { freedom }\end{array}$ & & $\begin{array}{l}-0.016 \\
(0.008)\end{array}$ & $\begin{array}{l}-0.016 \\
(0.008)\end{array}$ & $\begin{array}{l}0.11^{* * *} \\
(0.019)\end{array}$ & $\begin{array}{l}0.112^{* * *} \\
(0.019)\end{array}$ \\
\hline $\begin{array}{l}\text { Corruption } \\
\text { control }\end{array}$ & $\begin{array}{l}0.028^{*} \\
(0.012)\end{array}$ & & & & \\
\hline Rule of law & & $\begin{array}{l}0.568^{* * *} \\
(0.101)\end{array}$ & $\begin{array}{l}0.523^{* * *} \\
(0.107)\end{array}$ & $\begin{array}{l}0.509^{*} \\
(0.231)\end{array}$ & $\begin{array}{l}0.628^{* *} \\
(0.241)\end{array}$ \\
\hline Human capital & $\begin{array}{c}0.175 \\
(0.101)\end{array}$ & & & & \\
\hline Power distance & & $\begin{array}{l}-0.001 \\
(0.002)\end{array}$ & $\begin{array}{c}0.0 \\
(0.002)\end{array}$ & $\begin{array}{l}0.011^{*} \\
(0.005)\end{array}$ & $\begin{array}{c}0.01 * \\
(0.004)\end{array}$ \\
\hline Individualism & & $\begin{array}{c}0.001 \\
(0.002)\end{array}$ & $\begin{array}{c}0.001 \\
(0.002)\end{array}$ & $\begin{array}{c}0.0 \\
(0.005)\end{array}$ & $\begin{array}{l}-0.002 \\
(0.005)\end{array}$ \\
\hline Masculinity & & $\begin{array}{l}-0.002^{*} \\
(0.001)\end{array}$ & $\begin{array}{l}-0.003^{*} \\
(0.001)\end{array}$ & $\begin{array}{c}0.004 \\
(0.003)\end{array}$ & $\begin{array}{c}0.005 \\
(0.003)\end{array}$ \\
\hline $\begin{array}{l}\text { Uncertainty } \\
\text { avoidance }\end{array}$ & & $\begin{array}{l}-0.005^{*} \\
(0.002)\end{array}$ & $\begin{array}{l}-0.004^{*} \\
(0.002)\end{array}$ & $\begin{array}{l}0.017^{\star * *} \\
(0.005)\end{array}$ & $\begin{array}{l}0.015^{\text {** }} \\
(0.005)\end{array}$ \\
\hline $\begin{array}{l}\text { Public } \\
\text { employee ratio }\end{array}$ & & & $\begin{array}{l}-0.002 \\
(0.001)\end{array}$ & & $\begin{array}{c}0.005 \\
(0.003)\end{array}$ \\
\hline Constant & $\begin{array}{c}0.158 \\
(0.167)\end{array}$ & $\begin{array}{l}-5.009 \\
(2.367)\end{array}$ & $\begin{array}{l}-6.119^{*} \\
(2.535)\end{array}$ & $\begin{array}{c}1.282 \\
(5.411)\end{array}$ & $\begin{array}{c}4.256 \\
(5.705)\end{array}$ \\
\hline $\mathbf{N}$ & 28 & 28 & 28 & 28 & 28 \\
\hline R2 & 0.913 & 0.945 & 0.948 & 0.907 & 0.914 \\
\hline
\end{tabular}

Note: 1) Significance: $\left.{ }^{* * *} \mathrm{p}<.001,{ }^{* *} \mathrm{p}<.01,{ }^{*} \mathrm{p}<.05 ; 2\right)$ Standard errors in parentheses.

Source: Authors' calculation. 
From the empirical results, it is evident that e-government maturity plays an important role in the establishment of government effectiveness and efficiency. This confirms our main hypothesis, stating that e-government maturity is positively and significantly associated with government effectiveness and efficiency. In addition, similar research has been conducted by Das et al. (2017) where the e-government maturity improved the information and communication technology infrastructure and rise gross domestic product. In the first stage regression, e-participation and corruption control significantly determine the prediction level of e-government maturity, while the other two variables (economic prosperity and human capital) do not. The second stage regressions of government effectiveness and efficiency apply the predicted value of e-government maturity as a key independent variable. As stated in Nam (2019, p. 15), "e-government maturity contributes to public perceptions of the overall high quality of government services, civil services, policy formation, and policy implementation". Therefore, the second stage models were divided into those including the public employee ratio and those that do not. The public employee ratio is negatively associated with government effectiveness, but does not have a significant influence on government efficiency on a sample of the EU-28. This result contradicts that of $\operatorname{Nam}(2019$, p. 15) where "the public employee ratio is negatively associated with government efficiency but does not have a significant influence on government effectiveness" on a sample of all countries in the world. The interesting fact is that variable rule of law is positive and significant in all second stage regression models, which is in line with the initial expectations. This variable is especially important because it determines the quality of contract enforcement, property rights, the police, courts and likelihood of crime and violence, which is important in the establishment of all public functions of government during the COVID-19 pandemic. As there are two models of second stage regression of government effectiveness and efficiency, there is also a different impact of the variables. In a model of government effectiveness, variables such as democracy and political stability are positive and significant, while the variables economic freedom, power distance, masculinity and uncertainty avoidance are negative. In addition to the fact that they are negative, the variables masculinity and uncertainty avoidance also have a significantly negative influence on the outcome variables. This can be explained, since the EU-28 countries imply valuing legitimacy over survival in order to have effective and efficient government. When observing the model of government efficiency, the empirical results are quite different. The results of variable democracy are negative and significant, while political stability is only negative, but not significant. Economic freedom is positive and significant which is opposite as in model with government effectiveness. Regarding the cultural dimension variables, all of them (except individualism) are positive and some of them are significant (power distance and uncertainty avoidance). To transform the traditional government system into an e-government model, which is a key for the proper functioning during the COVID-19 pandemic, these cultural dimension variables are very important. In an adaptive and flexible culture, many governmental organizations should be very fast in order to establish 
quick services for citizens and to make sure employees complete their tasks in a precise way. By creating such flexible organizations, unexpected challenges such as the COVID-19 pandemic could be solved quickly and effectively.

\section{Discussion and conclusion}

Nowadays, in scientific literature, the topic of e-government effectiveness and efficiency brings about a very dynamic discussion. Due to the rapidly increased development of information and communication technology and unfortunately owing to the COVID-19 pandemic, this topic is even more important. In line with economic theory, the quality of government and government performance strictly depends on effectiveness and efficiency. Besides this, it is very challenging to define effectiveness and efficiency. Hence, Osborne and Gaebler (1992) define efficiency as a measure of how much each unit of output costs, and effectiveness as a measure of the quality of output. This is especially emphasized in the public sector as one of the largest producers of information and services in public administration. Therefore, public administration should pursue modern public governance practices (Ravšelj and Hodžić, 2020).

The scientific literature does not provide a great deal of evidence and studies that examine both government efficiency and effectiveness with regard to promoting e-government development activity in the EU member countries, especially now during the COVID-19 pandemic. Therefore, this paper covers the existing lack of research on the influence of e-government maturity on government effectiveness and efficiency in the EU-28. In order to obtain empirical results, a two-stage least square regression (2SLS) has been applied, where government effectiveness and efficiency are two dependent variables. The empirical results showed that e-government maturity positively and significantly contributes to enhancing government effectiveness and efficiency in the EU28. In addition, the variable of rule of law plays an important role in all stage regression models. This is especially interesting, because it provides evidence that the quality of contract, property rights, the police, courts and likelihood of crime and violence are important determinants in the establishment of public functions. Similar to the research by Nam (2019), e-government significantly contributes to government effectiveness, but fails to raise government efficiency in a cross-country world view. The findings of this paper are beneficial for governments and policymakers in order to establish appropriate and quality public governance and practices that would serve as a basis for the implementation of additional COVID-19 measures. Despite the interesting results, the research is limited by the publicly available data for all the EU countries.

The United Nations (2020) point out that the COVID-19 pandemic has forced governments and societies to turn toward digital technologies to respond to the crisis in the short-term, recover from and resolve socio-economic repercussions in the mid-term, and reinvent existing policies and tools in the long term. To achieve all the objectives, governments should endeavor to implement an open government approach and use digital communication channels to provide consistent public information to their citizens. Governments need 
to accelerate the implementation of new digital technologies, such as artificial intelligence, block chain and drones. The effectiveness and efficiency of investments in these technologies, as presented in scientific literature, could contribute to the development of knowledge-based industries, a decrease in risk and management of national and global health risks. Cities and local governments will help in responding to the needs of their inhabitants with sophisticated digital platforms, tools, applications and smart technologies. In order to achieve the continuous development of e-government, special focus should be the continuous analysis of the needs in different life situations, like during the COVID-19 pandemic. Hence, the implementation of efficient digital government functions is necessary to bridge the gap between more and less digitally advanced societies.

We believe that our further research in the field of efficiency and effectiveness of e-government should be focused on examining the situation in each individual European Union country. Such research has not been conducted in this region of Europe (Dečman, 2018). This analysis is a necessary basis for analyzing the current situation, formulating a shared vision, preparing a general strategy, planning development priorities and activities, as well as for the constant monitoring and evaluating of sustainable e-government transformation and its impact on the economy and society.

\section{Acknowledgements}

The authors acknowledge the financial support from the Slovenian Research Agency (research core funding No. (P5-0093) and project No. (J5-1789)). 


\section{References}

ACAPS. (2020). The COVID-19 Government Measures Dataset. At <https://www. acaps.org/covid-19-government-measures-dataset>, accessed 27 January 2021.

Afonso, A. et al. (2003). Public sector efficiency: an international comparison. Working Paper No. 242, European Central Bank Working Paper Series.

Alwashmi, M. F. (2020). The use of digital health in the detection and management of COVID-19. International Journal of Environmental Research and Public Health, 17(8), pp. 1-7. https://doi.org/10.3390/ijerph17082906.

Andersen, T. B. (2009). E-Government as an anti-corruption strategy. Information Economics and Policy, 21(3), pp. 201-210. https://doi.org/10.1016/j.infoecopol.2008.11.003

Angrist, J. D. and Imbens, G. W. (1995). Two-stage least squares estimation of average causal effects in models with variable treatment intensity. Journal of the American Statistical Association, 90(430), pp. 431-442. https://doi.org/10 .1080/01621459.1995.10476535

Bayer, C. et al. (2020). The Coronavirus Stimulus Package: How Large Is the Transfer Multiplier? CEPR Working Paper No. 14600.

Bertot, J. C. et al. (2012). Promoting transparency and accountability through ICTs, social media, and collaborative e-government. Transforming Government: People, Process and Policy, 6(1), pp. 78-91. https://doi.org/ 10.1108/17506161211214831

Cheng, C. et al. (2020). Covid-19 Government Response Event Dataset (CoronaNet v. 1.0). Nature Human Behaviour 4(7), pp. 756-768. https://doi. org/10.1038/s41562-020-0909-7

Ciborra, C. (2005). Interpreting e-government and development: Efficiency, transparency or governance at a distance? Information Technology \& People, 18(3), pp. 260-279. https://doi.org/10.1108/09593840510615879

Council of Europe. (2020). At <https://rm.coe.int/prems-120820-gbr-2051-digital -solutions-to-fight-covid-19-text-a4-web-/16809fe49c>, accessed 25 January 2021.

Das, A. et al. (2017). A longitudinal study of e-government maturity. Information \& Management, 54(4), pp. 415-426. https://doi.org/10.1016/j.im.2016.09.006

Dečman, M. (2018). The Analysis of E-Government Services Adoption and Use in Slovenian Information Society between 2014 and 2017. Central European Public Administration Review, 16(2), pp. 193-215. https://doi.org/10.17573/ сераг.2018.2.10.

Di Matteo, L. (2013). Measuring Government in the Twenty-first Century: An International Overview of the Size and Efficiency of Public Spending. Fraser Institute. https://www.fraserinstitute.org>, accessed 22 January 2021.

Economist Intelligence Unit Democracy Index. (2019). At <https://www.eiu. com/n/campaigns/democracy-index-2020/ >, accessed 25 January 2021.

European Commission. (2020). eGovernment Benchmark 2020: eGovernment that works for the people. Luxembourg: Publications Office of the European Union. doi: 10.2759/24753

Eurostat. (2019). National accounts indicator (ESA 2010).

Eyob, E. (2004). E-government: Breaking the frontiers of inefficiencies in the public sector. Electronic Government: An International Journal, 1(1), pp. 107-114. https://doi.org/10.1504/EG.2004.004140 
Global Competitiveness Index. 2018. At <https://www.weforum.org/ reports?year=2018\#filter>, accessed 27 January 2021.

Gourinchas, P.O. (2020). Flattening the pandemic and recession curves. In R. Baldwin and B. W. di Mauro, eds., Mitigating the COVID Economic Crisis: Act Fast and Do Whatever It Takes. VoxEu. Org. CEPR Press, pp. 31-39

Gupta, S. and Verhoeven, M. (2001). The efficiency of government expenditure. Experiences from Africa. Journal of Policy Modelling, 23(4), pp. 433-467. https://doi.org/10.1016/S0161-8938(00)00036-3

Grimmelikhuijsen, S. et al. (2013). The effect of transparency on trust in government: A cross-national comparative experiment. Public Administration Review, 73(4), pp. 575-586. https://doi.org/10.1111/puar.12047

Hauner, D. and Kyobe, A. (2010). Determinants of Government Efficiency, World Development, 38(11), pp. 1527-1542. https://doi.org/10.1016/j.worlddev.2010.04.004

Hackney, R. et al. (2007). Towards an e-Government efficiency agenda: The impact of information and communication behavior on e-Reverse auctions in public sector procurement. European Journal of Information Systems, 16(2), pp. 178-191. https://doi.org/10.1057/palgrave.ejis.3000677

Heeks, R. (1999). Reinventing government in the information age: International practice in IT-enabled public sector reform. London: Psychology Press.

Heritage Foundation (2019). At <https://www.heritage.org/index/>, accessed 27 January 2021.

Hofstede Center. (2019). At <https://hi.hofstede-insights.com/national-culture>, accessed 27 January 2021.

Hofstede, G. (1980). Culture's Consequences: International Differences in Workrelated Values. Beverly Hills, CA: Sage Publications.

Hofstede, G. (1983). National cultures in four dimensions. International Studies of Management and Organization, 13(1-2), pp. 46-74.

Justice, J. et al. (2006). E-government as an instrument of fiscal accountability and responsiveness: Do the best practitioners employ the best practices? The American Review of Public Administration, 36(3), pp. 301-322. https://doi. org/10.1177/0275074005283797

Kaufmann, D. et al. (2010). The Worldwide Governance Indicators: Methodology and Analytical Issues. World Bank Policy Research Working Paper No. 5430. https://ssrn.com/abstract=1682130>, accessed 22 January 2021.

Lindgren, I. and Jansson, G. (2013). Electronic services in the public sector: A conceptual framework. Government Information Quarterly, (30)2, pp. 163-172. http://dx.doi.org/10.1016/j.giq.2012.10.005.

Mandl, U. et al. (2008). The Effectiveness and Efficiency of Public Spending. Economic Papers No. 301. European Commission, Economic and Financial Affairs.

Nam, T. (2019). Does E-Government Raise Effectiveness and Efficiency? : Examining the Cross-National Effect. Journal of Global Information Management, 27(3), pp. 120-138. https://doi: 10.4018/JGIM.2019070107

Narayanan, B. G. et al. (2021). A method to analyze the sectoral impact of Fiscal support for COVID-19 affected economies: The case of Oceania, MethodsX, 8, pp. 1-9. https://doi.org/10.1016/j.mex.2021.101293

OECD. (2010). Efficient e-Government for Smarter Public Service Delivery. Denmark 2010. Assessment and Proposals for Action. OECD e-Government Studies. 
OECD. (2020). Tackling Coronavirus (COVID-19): Contributing to a Global Effort. Paris.

OECD. (2021). Open data in action: initiatives during the initial stage of the COVID-19 pandemic. Paris.

Open Government Partnership. (2020). At <https://www.opengovpartnership. org/collecting-open-government-approaches-to-covid-19/>, accessed 20 January 2021.

Osborne, D. and Gaebler, T. (1992). Reinventing Government: How the Entrepreneurial Spirit is Transforming the Public Sector. Reading, MA: Addison-Wesley Publishing Company.

Pina, V. et al. (2007). Are ICTs promoting government accountability? : A comparative analysis of e-governance developments in 19 OECD countries. Critical Perspectives on Accounting, 18(5), pp. 583-602. https://doi.org/10.1016/j. сра.2006.01.012

Ravšelj, D. and Hodžić, S. (2020). The Role of Public Governance Practices for Business R\&D Activity in the EU. Central European Public Administration Review, 18(1), pp. 125-141. https://doi: 10.17573/cepar.2020.1.06

Rayp, G. and Van De Sijpe, N. (2007). Measuring and explaining government efficiency in developing countries. The Journal of Development Studies, 43(2), pp. 360-381. https://doi: 10.1080/00220380601125230

Reddick, C. G. (2006). Information resource managers and E-government effectiveness: A survey of Texas state agencies. Government Information Quarterly, 23(2), pp. 249-266. https://doi.org/10.1016/j.giq.2005.11.006

Reddick, C. G. (2009). Factors that explain the perceived effectiveness of e-government: A survey of United States city government information technology directors. International Journal of Electronic Government Research, 5(2), pp. 1-15. https://doi.org/10.4018/jegr.2009040101

Relly, J. E. and Sabharwal, M. (2009). Perceptions of transparency of government policymaking: A cross-national study. Government Information Quarterly, 26(1), pp. 148-157. https://doi.org/10.1016/j.giq.2008.04.002

Rodríguez Bolívar, M. P. (2014). The Need for Analyzing e-Government Efficiency: An Introduction. In M. P. Rodríguez Bolívar, ed., Measuring E-government Efficiency: The Opinions of Public Administrators and Other Stakeholders, New York: Springer, pp. 1-7.

Siddik, A. N. (2020). Economic stimulus for COVID-19 pandemic and its determinants: evidence from cross-country analysis. Heliyon, 6, pp. 1-10. https://doi. org/10.1016/j.heliyon.2020.e05634

Slijepčević, S. (2010). Efikasnost i učinkovitost javne uprave: Hrvatska na putu prema Europskoj uniji. In A. Mišić, ed., Zbornik s V. međunarodnog simpozija »Institucionalni okvir i realne pretpostavke za reformu financijskog sustava BiH sukladno standardima (zahtjevima) Europske komisije«. Mostar: Fircon d.o.o. Mostar, pp. 319-334.

Shaw, R., Y.K. Kim and J. Hua. (2020). Governance, technology and citizen behaviour in a pandemic: lessons from COVID-19 in East Asia. Progress in Disaster Science, 6(100090), pp. 1-11, https ://doi.org/10.1016/j.pdisa s.2020.100090.

Schuppan, T. (2009). E-Government in developing countries: Experiences from sub-Saharan Africa. Government information quarterly, 26(1), pp. 118-127. https://doi.org/10.1016/j.giq.2008.01.

Tanzi, V. (1995). Government Role and the Efficiency of Policy Instruments. IMF Working Papers 1995/100, International Monetary Fund. 
Tanzi V. (1998). Government Role and the Efficiency of Policy Instruments. In P. B. Sørensen, ed., Public Finance in a Changing World. London: Palgrave Macmillan, pp. 51-69.

Tanzi, V. et al. (2007). Public Sector Efficiency: An International Comparison. Fraser Institute. At <https://www.fraserinstitute.org/sites/default/files/measuring-government-in-the-21st-century.pdf>, accessed 22 January 2021.

Ullah, A. et al. (2021). The Role of E-Governance in Combating COVID-19 and Promoting Sustainable Development: A Comparative Study of China and Pakistan. Chinese Political Science Review, 6, pp. 86-118. https://doi.org/ 10.1007/s41111-020-00167-w.

United Nations (2018). E-Government Survey 2018. At <https://publicadministration.un.org/egovkb/en-us/Reports/UN-E-Government-Survey-2018>, accessed 27 January 2021.

United Nations (2019). E-Government Survey 2019. At <https://publicadministration.un.org/en/Research/World-Public-Sector-Reports>, accessed 27 January 2021.

United Nations (2020). E-Government Survey 2020. Digital Government in the Decade of Action for Sustainable Development, New York: United Nations, Department of Economic and Social Affairs. At < https://publicadministration.un.org/egovkb/Portals/egovkb/Documents/un/2020-Survey/2020\%20 UN\%20E-Government\%20Survey\%20(Full\%20Report).pdf/>, accessed 21 January 2021.

Welch, E. et al. (2005). Linking citizen satisfaction with e-government and trust in government. Journal of Public Administration Research and Theory, 15(3), pp. 371-391. https://doi.org/10.1093/jopart/mui021

West, D. M. (2004). E-government and the transformation of service delivery and citizen attitudes. Public Administration Review, 64(1), pp. 15-27. https://doi. org/10.1111/j.1540-6210.2004.00343.x

World Governance Indicators. (2019). At <https://info.worldbank.org/governance/ wgi//>, accessed 27 January 2021.

Zugravu, B. G. and Sava, A. Ş. (2012). Recent Changes in Public Sector Efficiency in Romania: Determinants and Implications. Procedia - Social and Behavioral Sciences, 58(12), pp. 423-433. https://doi.org/10.1016/j.sbspro.2012.09.1019. 